\title{
Market size of the media industry and freedom of press: an empirical study
}

\author{
Evguenii Zzdravnykh* \\ Faculty of Economics, Saint-Petersburg State University, Russia
}

Received: 3 November 2013

Revised: 30 June 2014

Accepted: 26 September 2014

\begin{abstract}
This paper empirically shows that the market size of the media sector is important for freedom of the press, in addition to the wealth of the country and type of political regime. I estimated freedom of the press using three variables: size of the media market, GDP per capita and the type of political regime. Freedom of the press was estimated using data for 48 countries from 2006 till 2009. The most important variable influencing freedom of the press is the type of political regime, but the size of the media market is also important. In countries with a larger media market, the press is freer.
\end{abstract}

Keywords: freedom of the press, media industry, interaction effects

JEL Classification Codes: Z10, L82

\section{Introduction}

Freedom of the press is an essential condition for a transparent and democratic government, as the media must be independent in order to express information objectively. However, an independent press requires a social, political and economic environment that encourages professional, independent and free journalism. Thus it is two-way causality. Because more democratic governments usually more open and transparent and hence this fact helps to media companies achieve independence and prepare objective articles.

Press freedom is also expensive, and thus higher revenues are required for greater independence and freedom. For example, an independent media outlet needs to hire professional and independent journalists, a significant expense. The best media sources are thus likely to be the richest. Additionally, in developed counties, it is easier to maintain an independent media company than in developing or impoverished countries. This thesis was confirmed by Jacobsson et al. (2002), who found that economic wealth attracts more money for commercial advertising, thus allowing the media to become less dependent on political financing and hence freer.

\footnotetext{
*E-mail: evgeniy.zazdravnyh@mail.ru.

Citation: Zazdravnykh, E. (2014) Market size of the media industry and freedom of press: an empirical study, Economics and Business Letters, 3(2), 109-114.
} 
On the other hand small market size might associate with only few media companies which may earn high profit. In addition to earning those firms need incentives for better journalistic work. And this depends on many circumstances such as competition, education, professional level of journalists and ability to establish own new media company. Latter case is important because employees of journalistic start-up more interested in better work than their experienced colleagues from well-known editions in cause of competition and desire to make successful start-up. But when market size is small it would be difficult. For example, (1) when exists few medias on the market it will be few journalists on a job market. Consequently competition between them might be low and hence incentives for better practice would not be high. (2) If exists many firms on a small markets they will earn low profit and pay low wages. Thus this job will be unattractive for high-skilled people and they would choose other related to journalism work.

In addition, in countries where the media market is smaller, we suggest that the press will earn less money. Moreover, in such a market, media outlets face less competition and, consequently, have less need to improve their performance. Therefore, the press in countries with a limited media market is unlikely to be free. This paper explores the question: is it true that freedom of the press is lower in countries where the media market is smaller?

\section{Theory review and variables}

Many previous studies have analyzed the relationship between freedom of the press, corruption, political rights, democracy and economic development. For example, Themudo (2003) and Brunetti and Weder (2003) found that in countries with less corruption, greater press freedom exists. Chowdbury (2004) built upon this research by demonstrating that democracy and press freedom have a significant influence on corruption. Similar results were obtained by Charron (2009) and others.

In close connection with these studies, several researchers have explored the relationships between democracy, human and political rights and media freedom. For instance, Pal (2011) showed that free media may decrease various forms of socio-political instability. Starr (2012) describes how the development of digital technologies and communications affects freedom of the press.

A number of authors have studied the impact of legislation and institutions on press freedom, including Hazell and Worthy (2010), Rabina (1999), McClean (2010) and Nam (2012). These studies showed that legislation's influence on press freedom depends on the type of political regime, the level of corruption and total economic development. Others have investigated how the economy impacts media freedom. Dutta et al. (2009) showed that foreign direct investment is necessary for a free press.

In the present study, I included both economic and political variables in the tested model.

\section{Method and data}

In this paper, two measures of press freedom were used: the Freedom of Press Index by Reporters Without Borders (France) and the Freedom of the Press Index by Freedom House (USA). These two indexes were used together to draw more exact conclusions because both indices face the criticism that they reflect the opinion of their authors and thus might not be absolutely objective. In both indices, smaller values indicate more freedom and vice-versa. The former index reflects the degree of freedom that journalists, news organizations and netizens enjoy in each country, and the efforts made by the authorities to respect and ensure respect for this freedom (Reporters Without Borders, 2013). This index is based on 
questionnaire that is sent by Reporters Without Borders to partner organizations (15 freedom expression NGOs located in all five continents), to network of around 130 correspondents, to journalists, researchers and human rights activists. It is cover around 175 countries, others is not included because of a lack of reliable and confirmed data. The score range from 0 to more than 100 where 0 means the best possible score and 100 and more is worse (Reporters Without Borders, 2009).

The latter, Freedom of Press Index which is measured by Freedom House is also based on survey of 195 countries. It assesses the degree of print, broadcast, and internet freedom in every country in the world. And the index accounts the legal environment for the media, political pressures that influence reporting, and economic factors that access to information. It provides numeral rankings for each country where lower score means more freedom and higher score is low freedom (Freedom House, 2013).

Data from 48 countries from 2006 till 2009 was used for this study. This time range was chosen because data sets for other variables are available only till 2009 year. The number of countries in this dataset was reduced because other datasets contain fewer countries (48). It is caused by a lack of data for many countries for all years. The list of countries which are classified by area is presented in Table 1 .

Table 1. Classification of countries by area

\begin{tabular}{ll}
\hline \hline Area & Countries \\
\hline \hline & Austria, Belgium, Bulgaria, Cyprus, Czech Republic, Denmark, Estonia, Finland, \\
& France, Georgia, Germany, Greece, Hungary, Ireland, Italy, Latvia, Lithuania, \\
& Netherlands, Norway, Poland, Portugal, Romania, Slovakia, Slovenia, Spain, \\
Europe & Sweden United Kingdom, Azerbaijan, Turkey \\
North America & - \\
South America & Ecuador, Peru, Uruguay \\
Asia & India, Malasya, Nepal, Vietnam \\
Africa & Egypt, Malawi, Morocco, Senegal, Thailand \\
Oceana & Australia, Indonesia, Phillipines \\
Middle East & Iran, Jordan, Kyrgyzstan, Pakistan \\
\hline \hline
\end{tabular}

Media market size was measured by the value added by the publishing of newspapers, journals, etc., as determined using INDSTAT- United Nations Industrial Development Organization Data. To avoid the effect of differences in countries' spatial and economic sizes, these data were divided by the total value added in the country's economy. Raw data were in units of current prices in national currencies. In this paper, value-added data were converted to US dollars using World Bank and OECD data on exchange rates for the corresponding year.

Next, the INDSTAT data were used to measure the total wealth of each country's economy. A measure of total wealth was needed because some countries, including Russia, Qatar, Saudi Arabia, etc., have high GDP per capita (in US dollars, current prices) according to the World Bank, but the press in these countries is not free. Thus, GDP per capita was used as the measure of national wealth to assess the impact of the ratio of media companies' wealth to total countries' wealth on freedom of the press. I used GDP in current prices instead PPP (Purchasing Power Parity) for consistency with Value added of those countries.

Following Nam (2012), democracy was measured using Freedom House's data on political rights and civil liberties from its Freedom of the World Report. Using Freedom House's scale, 
the Democracy Index, countries are scored from 1 to 14, where the lowest score (1) denotes free status and the highest score (14) indicates a lack of civil liberties and political freedom.

Descriptive statistics for all variables studied are shown in Table 1.

Table 2. Descriptive Statistics: Common Sample

\begin{tabular}{|c|c|c|c|c|c|}
\hline & $\begin{array}{c}\text { Freedom of } \\
\text { Press Index } \\
\text { (Reporters } \\
\text { Without } \\
\text { Borders) }{ }^{1}\end{array}$ & $\begin{array}{l}\text { Freedom of } \\
\text { the Press } \\
\text { Index } \\
\text { (Freedom }^{2} \text { House) }\end{array}$ & $\begin{array}{c}\text { Value added } \\
\text { by press/Total } \\
\text { value added, } \\
\%\end{array}$ & $\begin{array}{l}\text { Gross Domestic } \\
\text { Product per } \\
\text { capita, (current } \\
\text { prices, US } \\
\text { dollars) }^{3}\end{array}$ & $\begin{array}{c}\text { Democracy } \\
\text { Index }^{4}\end{array}$ \\
\hline Mean & 21,043 & 36,089 & 0,00189 & 19367,800 & 4,721 \\
\hline Median & 11,945 & 28,000 & 0,00167 & 11101,660 & 3,000 \\
\hline Std. Dev. & 22,134 & 21,572 & 0,00151 & 19969,290 & 3,358 \\
\hline Minimum & 0,000 & 9,000 & 0,000007 & 234,212 & 2,000 \\
\hline Maximum & 104,140 & 85,000 & 0,006 & 95189,870 & 12,000 \\
\hline Observations & 240 & 192 & 137 & 240 & 240 \\
\hline Years & 2006-2010 & 2006-2009 & 2006-2010 & 2006-2010 & $2006-2010$ \\
\hline \multicolumn{6}{|c|}{1 http://en.rsf.org/press-freedom-index-2013,1054.html } \\
\hline \multicolumn{6}{|c|}{$2 \mathrm{http}: / /$ www.freedomhouse.org/report-types/freedom-press } \\
\hline 3 http://data.worl & ank.org/indicator & IDP.PCAP.CD & & & \\
\hline
\end{tabular}

In Table 2, we see that mean of the Freedom of Press Index by Reporters Without Borders is almost two times lower than Freedom House's index. The standard deviations of two indices, however, are very similar. Minimum of the former variable is equal to 0 , which means that in this dataset exist countries with almost absolute free press. Number of observations less than 240 is due to the shorter time period. It covers 2006-2009 years in comparison to 2006-2010 years.

The data on the value added by the press shows that the variation among the observed countries is high; the standard deviation is $0.15 \%$, compared to an average value of 0.19 and a median of $0.17 \%$. Number of observations less than 240 is because of existence of missing variables.

The GDP per capita data reveals the greatest differences among the countries. The standard deviation is 19969.3 dollars per capita, the mean is $\$ 19367.8$ dollars per capita, and the median is 11101.7 dollars per capita.

The Democracy index average is 4.7, indicating that the countries studied here show relatively high levels of democracy. The median is 3 , meaning that the group of countries shows high voice accountability and protection of political rights. However, the maximum is 12 out of 14 .

\section{Results}

The following model was estimated using GLS (General Least Squares) for avoiding heteroscedasticity between countries:

$$
\operatorname{Ln}(F P I)_{i t}=C+\beta_{1} \operatorname{Ln}(V A)_{i t}+\beta_{2} \operatorname{Ln}(G D P P C)_{i t}+\beta_{3} \operatorname{Ln}(\text { Demo })_{i t}
$$


Where $\operatorname{Ln}(F P I)_{i t}$ is the natural log of the freedom of press index, $\operatorname{Ln}(V A)_{i t}$ is the natural $\log$ of the share of value added by the press in the total value added, and $\operatorname{Ln}(G D P P C)_{i t}$ is the natural log of the GDP per capita.

Table 3 shows estimations for two dependent variables. The first estimation is calculated using the Reporters Without Borders index. Here, we see that the press's earning measure is significant and that its coefficient value is almost equal to that of GDP per capita's coefficient. Thus, we conclude that media companies' earnings in a given country are as important as the country's overall wealth in determining its level of freedom of the press. However, the level of democracy is more important; the democracy index's coefficient is significant and high. This result suggests that in more democratic countries, the press will be both freer and richer.

The same results were produced in the estimation using Freedom House's index of freedom of the press. Media companies' earnings were again significant and had a positive impact on freedom of the press. However, the coefficient representing media companies' earnings was the least among the included variables. Gross domestic product per capita is significant to and has a positive relationship with press freedom. Again, the results suggest that in wealthier countries with a richer media, freedom of the press will be higher. Democracy is significant and also has a positive impact on freedom of the press. Hence, in more democratic countries, we have a freer press. Overall, the results of the two estimations are equal.

Table 3. Estimations

\begin{tabular}{lcc}
\hline \hline & \multicolumn{2}{c}{ Dependent Variable } \\
Variables & Ln(Freedom of Press Index by Reporters & Ln(Freedom of the Press Index by \\
& Without Borders) & Freedom House) \\
\hline Ln(VA) & $-0,11111323^{* * *}$ & $-0,04467139 * * *$ \\
St. Error & 0,01929137 & 0,00569537 \\
t-Statistics & $-5,76$ & $-7,84$ \\
Ln(GDPPC) & $-0,09649473 * *$ & $-0,10438492 * * *$ \\
St. Error & 0,03501972 & 0,00550483 \\
t-Statistics & $-2,76$ & $-18,96$ \\
Ln(Demo) & $1,2160738^{* * *}$ & $0,65124998 * * *$ \\
St. Error & 0,07427849 & 0,0232543 \\
t-Statistics & 16,37 & 28,01 \\
Constant & $0,88477499^{* *}$ & $3,1764097 * * *$ \\
St. Error & 0,39206791 & 0,0475574 \\
t-Statistics & 2,26 & 66,79 \\
Observations & 137 & 130 \\
\hline \hline$* * *$ variable significant at $99 \%$ level & & \\
$* *$ variable significant at 95\% level & &
\end{tabular}

\section{Conclusions}

This paper empirically demonstrates that the most important factor influencing freedom of the press is the political regime. In more democratic countries with higher levels of political rights and voice accountability, we have a freer press. As described above, many other 
researchers have tested this thesis previously. It is important to note that this process has twoway causality between democracy, political regime and the freedom of press.

The total wealth of the country is less important than the level of democracy in influencing freedom of the press. The results obtained here confirmed that in places with a higher GDP per capita, we tend to find a more independent press. This idea has been developed previously by Jacobsson et al. (2002).

The media market size is also important in determining a country's freedom of the press. In countries with a higher media market size, the press tends to be freer. This is most likely because with a larger media market, there will be more media companies and hence a more competitive environment. Consequently, journalists have more motivation to excel, resulting in a more independent and freer press.

Moreover, the freedom of press is subjective measurement which in fact reflects opinion of the organization or organizations. The same conclusion is fair for evaluation of political regime. Thus results of this paper should be considered carefully and the reader should keep in mind that those indexes are not absolutely truth despite to similarity of results which were obtained from two estimations.

\section{References}

Brunetti, A. and Weder, B. (2003) A free press is bad news for corruption, Journal of Public Economics, 87(7/8), 1801-1824.

Charron, N. (2009) The impact of socio-political integration and press freedom on corruption, Journal of Development Studies, 45(9), 1472-1493.

Chowdbury, S.K. (2004) The effect of democracy and press freedom on corruption: an empirical test, Economic Letters, 85, 93-101.

Dutta, N. and Roy, S. (2009) The impact of foreign direct investment on press freedom, Kyklos, 62(2), 239-257.

Hazell, R. and Worthy, B. (2010) Assessing the performance of freedom of information, Government Information Quarterly, 27(4), 352-359.

Jacobsson, A. and Jacobsson, E.M. (2002) Freedom of the press and economic development, 17th European Economic Association Annual Congress, 22-24, Venice, Italy.

McClean, T. (2010) Who pays the piper? The political economy of freedom of information, Government Information Quarterly, 27(4), 392-400.

Nam, T. (2012) Freedom of information legislation and its impact on press freedom: a crossnational study, Government Information Quarterly, 29(4), 521-531.

Pal, S. (2011) Media freedom and socio-political instability, Peace Economics, Peace Science, \& Public Policy, 17(1), 1-21.

Rabina, D. (1999) Foil and foia compared: a comparison between the freedom of information law in Israel and the U.S. freedom of information act, Journal of Government Information, 26(2), 89-108.

Starr, P. (2012) An unexpected crisis: the news media in postindustrial democracies, International Journal of Press/Politics, 17(2), 234-242.

Themudo, N. (2003) Reassessing the impact of civil society: nonprofit sector, press freedom, and corruption, Governance, 26(1), 63-89. 